\title{
AN AYURVEDIC MANAGEIMENT OF VARICOSE ULCER: A CASE STUDY
}

KEY WORDS:

Jalaukavacharana, Yogavasthi, Avagaha.

\section{Dr.Manju.P*}

\section{Dr.T Thomas}

\section{Dr.Sindhu Das.H}

Final Year MS Scholar, Department of Salyatantra, Sree Narayana Institute of Ayurvedic Studies \& Research, Pangode, Puthur, Kollam 691507(Pin) *Corresponding Author

Professor \& HOD (Rtd.), Department of Salyatantra, Sree Narayana Institute of Ayurvedic Studies \& Research, Pangode, Puthur, Kollam 691507(Pin).

Associate Professor, Department of Salyatantra, Sree Narayana Institute of Ayurvedic Studies \& Research, Pangode, Puthur, Kollam 691507(Pin)

A male patient aged 37 yrs came to Salyatantra OPD of Sree Narayana Institute of Ayurvedic Studies \& Research Hospital, Puthoor, Kollam with complaints of a non-healing wound on left medial malleolus since 6 months. Discharge and itching

다일 around wound since 10 days. Pain over inguinal region since 2 days and came here for better management. On examination there was a vertically oval shaped ulcer with slopping edge and the floor was covered with red granulation tissue and white margin on left medial malleolus. On palpation there was temperature rise and tenderness and inguinal lymph node enlargement. The diagnosis was confirmed as varicose ulcer. Patient was treated with Jalaukavacharana for 2 days, Yogavasthi and Avagaha and dressing with Jathyadi Ghrita and crepe bandaging for 9 days along with internal medication. The wound responded well with each treatment procedures. The wound was completely healed. Follow up was done on 7th day and 14th day of discharge. There was complete closure wound. No reappearance of disease since three months. Thus this patient was successfully treated with this Ayurvedic protocol without any recurrence and complications.

\section{INTRODUCTION}

Varicose ulcer is the most severe and debilitating outcome of chronic venous insufficiency in the lower limbs and accounts for 80 percent of lower extremity ulcerations. In the course of a lifetime, almost $10 \%$ of the population will develop a chronic wound, with a wound-related mortality rate of $2.5 \%$. While there are few Indian studies on the epidemiology of chronic wounds, one study estimated the prevalence at 4.5 per 1000 population. The high prevalence of varicose ulcer has a significant socio economic impact in terms of medical care, days away from work and reduced quality of life. Varicose ulcer are the wounds occurring due to inappropriate functioning of venous valves, usually of the legs mostly along medial malleolus. Which is often very painful, can bleed, and get infected. Treating varicose ulcers is a difficult task to the physician and a nightmare to the suffering patients.

According to Ayurvedic classics, varicose ulcers can be correlated with the the concept of DuaVraa and can be treated accordingly. Acharya Susrutha has detailed Shashtirupakrama (60 modalities of treatments) in Vrana Chikitsa.

This work is a single case study on Ayurvedic line of management followed in the Department of Salyatantra, Sree Narayana Institute of Ayurvedic Studies and Research. Here we incorporated the treatments such as Jaloukavacharana, Sveda (Avagaha), Alepa, Bandhana and Vasthi from Sashtirupakrama along with internal medication for successful management of varicose ulcer.

\section{CASE REPORT}

A male patient aged 37 yrs came to Salyatantra OPD of Sree Narayana Institute of Ayurvedic Studies \& Research Hospital Puthoor with complaints of a wound on left medial malleolus with pain since 6 months. Discharge and itching around wound since 10 days. Pain over inguinal region since 2 days and came here for better management. On examination there was a vertically oval shaped ulcer with slopping edge and the floor is covered with red granulation tissue, white margin on left medial malleolus. The skin around wound is rough, dark coloured and oedematous. On palpation there was temperature rise and tenderness, hardening of skin and inguinal lymph node enlargement. The diagnosis was confirmed as varicose ulcer which can be classically correlated to Dushtavrana and Vrana chikitsa was applied. The patient was treated with Jalaukavacharana for 2 days, Yogavasthi, Avagaha and dressing with Jathyadi Ghrita for 9 days along with internal medications. Foot end elevation was maintained at night. Patient had $\mathrm{H} / \mathrm{O}$ diabetes mellitus, under medication since one year and had $\mathrm{H} / \mathrm{O}$ surgery for varicose vein before 15 yrs, No H/O Allergies to any food, any known medication, dust. No family history.

\section{SETTING FOR THE STUDY}

The selected patient diagnosed as varicose ulcer from O.P.D. of Salyatantra, Sree Narayana Institute of Ayurvedic Studies \& Research hospital Puthoor was admitted to I.P.D. on 7/11/19 with MRD No. 19110516 and discharged on 15/11/19. Data collection was done during the initial 9 days as IP and follow up on $7^{\text {th }}$ day, $14^{\text {th }}$ day and $90^{\text {th }}$ day of discharge.

\section{PLAN OF STUDY}

Prior to the therapy general information of both the patient and the disease were made. A complete history of the disease along with complaints were recorded, General systemic and local examinations were carried out. The parameters used to determine the outcome are length and breadth of ulcer followed by data collection during the treatment and followup periods.

\section{MATERIALS AND METHODES}

Table: 1, Materials and methods.

\begin{tabular}{|c|c|c|}
\hline METHODS & MATERIALS & DURATION \\
\hline JALOUKAVACHARAN & 2 Jaloukas & 2 days \\
W & Water & \\
& 4 Bowls & \\
Gloves & \\
& Gauze pieces & \\
& Cotton pads & \\
& Haridra (turmeric powder) & \\
& Bandages & \\
\hline
\end{tabular}




\begin{tabular}{|c|c|c|}
\hline YOGA VASTHY & \begin{tabular}{|c} 
For manjishtadi kashaya \\
vasthy \\
Saindhava-5gm \\
Madhu-80ml \\
Sahacharadi \\
Mezhukupakam-60ml \\
Manjishtadi Kalka $-40 \mathrm{gm}$ \\
(Manjishta, Triphala, \\
Guduchi, Nimbha, \\
Sathapushpa) \\
Manjishtadi Kashaya-100ml \\
Gomutra-100ml \\
Dhanyamla-100ml \\
For Matravasthi \\
Sahacharadi \\
Mezhukupakam-90ml
\end{tabular} & 3 days \\
\hline AVAGAHA & Triphala kashayam & 9 days \\
\hline ALEPA & Jathyadi ghritam & 9 days \\
\hline CREPE BANDAGE & Crepe & 9 days \\
\hline
\end{tabular}

\section{CRITERIA FOR ASSESSMENT}

Length and breadth of wound.

\section{OBSERVATION}

Table:2, Observations.

\begin{tabular}{|c|c|c|}
\hline Date of assessment & Length & Breadth \\
\hline $7 / 11 / 19$ & $5 \mathrm{~cm}$ & $3.5 \mathrm{~cm}$ \\
\hline $8 / 11 / 19$ & $4.5 \mathrm{~cm}$ & $3.2 \mathrm{~cm}$ \\
\hline $9 / 11 / 19$ & $3.5 \mathrm{~cm}$ & $2.8 \mathrm{~cm}$ \\
\hline $10 / 11 / 19$ & $3 \mathrm{~cm}$ & $2.5 \mathrm{~cm}$ \\
\hline $11 / 11 / 19$ & $2.8 \mathrm{~cm}$ & $2 \mathrm{~cm}$ \\
\hline $12 / 11 / 19$ & $2.5 \mathrm{~cm}$ & $1.5 \mathrm{~cm}$ \\
\hline $13 / 11 / 19$ & $2 \mathrm{~cm}$ & $1 \mathrm{~cm}$ \\
\hline $14 / 11 / 19$ & $1.5 \mathrm{~cm}$ & $0.5 \mathrm{~cm}$ \\
\hline $15 / 11 / 19$ & $1 \mathrm{~cm}$ & $0.3 \mathrm{~cm}$ \\
\hline
\end{tabular}

\section{RESULT}

- The wound length $5 \mathrm{~cm}$ reduced to $1 \mathrm{~cm}$ and breadth of 3.5 $\mathrm{cm}$ to $0.3 \mathrm{~cm}$ in 9 days.

- Follow up on $7^{\text {th }}$ day after discharge found wound length $0.5 \mathrm{~cm}$ and breadth $0.1 \mathrm{~cm}$

- Follow up on $14^{\text {th }}$ day after discharge found complete healing of wound with epithelialization

- Follow up on $90^{\text {th }}$ day found no reappearance of the condition.

\section{DISCUSSION AND CONCLUSION}

A venous ulcer is the common and recurrent form of leg ulcers encountered in general practice. Its improper care can cause gangrene and may require amputation of the affected limb. So it should be treated with care. In this study the adopted treatments are Jalaukavacharana for 2 days, Yogavasthi and Avagaha and dressing with Jathyadi Ghrita and crepe bandaging for 9 days along with internal medication Mahamanjishtadi Kashayam $60 \mathrm{ml}$ bd b/f, Kaisora Guggulu tab 1-0-1 with Kashayam, Tab Lesept 1-0-1 a/f.

Acharya mentions that the wound which have swelling, which are hard, darkred, painful deep and uneven bloodletting with Jalouka is beneficial. Jaloukavacharana provides analgesic, anti-inflammatory and mucolytic action hence helpful in curing pain, swelling and discharges. Avagaha reduces hard, dry and painful inflammation. Application of Jathyadi Ghrita help in Sodhana Ropana of Vrana. By bandaging wound become purified, soft and heals. Vasthi helps in relieving the pain and purification of wound. Administration of enema is indicated in wound which have more aggravation of Vata, which are dry greatly painful and situated especially in lower part of the body.

Through this case study it was observed that this protocol was very effective in varicose ulcer. The wound length $5 \mathrm{~cm}$ reduced to $1 \mathrm{~cm}$ and breadth of $3.5 \mathrm{~cm}$ to $0.3 \mathrm{~cm}$ by 9 days.

Follow up on 7 days after discharge found wound length $0.5 \mathrm{~cm}$ and breadth $0.1 \mathrm{~cm}$. Follow up on $14^{\text {th }}$ day after discharge found complete healing of wound with epithelialization.

\section{IMAGES: 1}
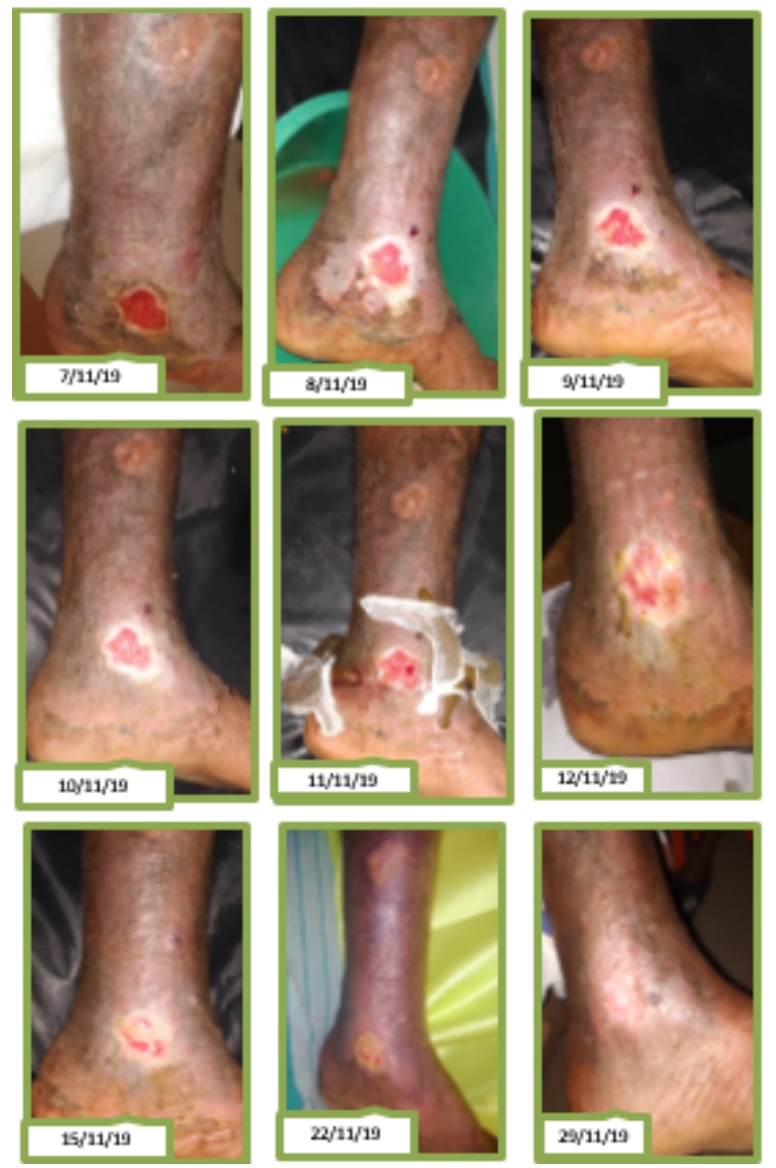

\section{REFERANCE}

1. Illustrated Susruta Samhita chikitsasthanam(Srikantha Murthy KR,trans,English) lst ed. Varanasi:Chaukhambha Orientalia;2014; 1:p.10,11,15,1623\&24.

2. Norman Williams S, Christopher bulstrode jk, Ronam o'connell P. Bailey and Loves Short Practice of Surgery.Boca raton:CPC Press Taylor and Francis group;2013.chapter 73,The anus and anal canal;p.1257.

3. 4. S Das, A Concise Textbook Of Surgery,9th edition,2016,Publisher- Dr Soman Das, chapter 16, page 159,267

4. Sriram Bhat M. SRB's manual of surgery, 5 ed. New Delhi: Jaypee Brothers Medical Publishers (P)Ltd;2016.chapter 25,rectum and anal canal;p.969.

5. Chakradatta, Indradev Tripathi, Chaukambha Sanskrit sansthan Varanasi,2005,PP 542, page no.455

6. Sargadhara samhita, Bramhanand Tripathi, Chaukamba Surbharti Prakashan, Varanasi, 2007, PP488, Page number 153. 